\title{
Cointegration Approach to the Estimation of the Long-Run Relations between Exchange Rates and Trade Balances in Visegrad Countries
}

\author{
Jana Šimáková \\ Silesian University in Opava \\ School of Business Administration in Karviná, Department of Finance and Accounting \\ Univerzitní náměstí 1934/3, 73340 Karviná, Czech Republic \\ E-mail: simakova@opf.slu.cz
}

\begin{abstract}
The paper deals with the relationship between exchange rates and foreign trade. The aim of this paper is to reveal the long-term effects of the level of exchange rates on the trade balances of the Visegrad Countries. As the different product categories are characterized by different price elasticity, exchange rate uncertainty sensitivity and countries are differentiated by consumer and producer behavior patterns, this paper uses territorial and commodity structuring of foreign trade data. An empirical analysis is performed for the period 1999: Q1-2014: Q3. The effects of exchange rate levels are analyzed by Johansen cointegration analysis to reveal the long-term effects. The approach adopted in this study is found to be an acceptable substitute for testing the Marshall-Lerner condition. Bilateral and majority of partial trade balances are cointegrated with bilateral exchange rate in the long term. Although there are some product categories without proved cointegration, the product categories tending to the long-term equilibrium significantly exceed them. Based on this analysis it can be stated that the bulk of the total and partial bilateral trade balances are characterized by a common long-term development with domestic and foreign GDP and bilateral exchange rates.
\end{abstract}

Keywords: cointegration, exchange rate, Marshall-Lerner condition, trade balance

JEL codes: F10, F31

\section{Introduction}

Exchange rate is one of the variables mediating the impact of external economic relations on the economic entities in the domestic country and influencing decisions of particular economic entities to export and import goods and services. Exchange rate is a quantitative variable that fluctuates over time and this movement, its speed and extent, affects the prices of goods and services and thus reflects the amount of the total cost, and revenue from foreign trade and the overall demand and supply of internationally traded goods. Therefore, exchange rate importance increases proportionally with the openness of the domestic economy to other countries. A region with high openness of economies can be represented by the Visegrad Group (V4). In 2015 the share of trade volume in the GDP was $96 \%$ in Poland, $160 \%$ in Hungary, $163 \%$ in the Czech Republic and $185 \%$ in Slovakia. This group is constituted of geographically close open economies located in Central Europe, which have successfully completed the transition process to the market economies. The 
transformation process influences their foreign trade and exchange rates regime as well. In this situation, the high rates of participation in foreign trade of V4 countries and a gradual inclination to floating exchange rates make the V4 eligible for the research.

In analyzing the relationship between exchange rate and foreign trade, this paper is based on the balancing process, which means linking the balance of trade with income and exchange rates. In a system of flexible exchange rates it is possible to eliminate the trade deficit through currency depreciation. The same principle can also be used for the system of a fixed exchange rate as a consequence of an official devaluation. The efficiency of depreciation (devaluation) to cope with the deficit in the trade balance is assessed by the indirect testing of Marshall-Lerner condition in this paper. The Marshall-Lerner condition states that the sum of export and import demand elasticity has to be at least one and then the currency depreciation has a positive impact on the trade balance. Usually, Marshall-Lerner condition is not met in the short run, goods tend to be inelastic and depreciation deteriorates the trade balance initially. In the long run, consumers can adjust to the new prices, volume effect is generally believed to dominate the price effect and trade balance will be improved.

Literature concerning the relationship between exchange rates and trade balance usually fall into one of the following three categories: studies using aggregate trade data; studies employing disaggregate trade data at the bilateral level; and recent studies using disaggregate trade data at the commodity level. The first type of studies concentrates on the use of aggregate export and import data between a country and the rest of the world in assessing the effectiveness of currency devaluation (e.g. Felrningham, 1988). These studies have to employ the effective exchange rate, which can be misleading when the country's currency appreciates against one currency and simultaneously depreciates against another currency (Bahmani-Oskooee and Brooks, 1999). The weighted averaging will therefore smooth out the effective exchange rate fluctuations, yielding an insignificant link between the effective exchange rate and the trade balance. Therefore, many other studies employ bilateral exchange rates and bilateral trade balance data between a country and its major trading partners (Bahmani-Oskooee and Ratha, 2004). There has been a growing body of literature arguing that the second-generation study may still suffer from the aggregation bias problem, as significant exchange rate impacts with some commodities could be more than offset by insignificant exchange rate effects with others, thereby resulting in an insignificant exchange rate impact and vice versa. Therefore, the newest studies disaggregate data to the industry level (e.g. BahmaniOskooee and Hegerty, 2011; Bahmani-Oskooee et al., 2014; Bahmani-Oskooee et al., 2016).

The aim of this paper is to reveal the long-term effects of the level of exchange rates on the trade balances of the Visegrad Countries. As the different product categories are characterized by different price elasticity, exchange rate uncertainty sensitivity and countries are differentiated by consumer and producer behavior patterns, this paper uses territorial and commodity structuring of foreign trade data. Therefore, this study substantially contributes to scientific discussion in this field and fills the gap in 
literature about territorial-commodity trade. An empirical analysis is realized for the period 1999-2014. The effects of exchange rates levels are analyzed by Johansen cointegration analysis to reveal the long-term effects. Following Arize (1994), the approach adopted in this study is found to be an acceptable substitute for testing the Marshall-Lerner condition.

\section{Development of Foreign Trade and Exchange Rates in V4 Countries}

The V4 countries are Central European countries which with their strategic position present an important entity for the foreign trade. They passed an important transformation phase after 1989, during which they reformed the system of centrally planned economies to the market economies. The new concept has become an important tool in building competitiveness of their national economies towards integration into the global market economy and to European structures. The transformation influenced their foreign trade and exchange rate policy issues as well. They redirect trade from east to west markets which has caused changed structure and intensity of trade flows and this trade bloc has turned into a region with a significant impact on the world foreign trade. However, the liberalization steps of individual countries have contributed to the growth of openness of the economies to different degrees.

\subsection{Development of Foreign Trade in V4 Countries}

As can be seen in Figure 1, the openness of all economies is increasing, but the growth rate varies across them. Furthermore, each country enters the beginning of the period with another share of the total foreign trade turnover of their GDP. The highest degree of openness at the beginning of the sample period was observed in Hungary (108\%). Nevertheless, its growth rate is far below Slovakia, which shifted from $71 \%$ to almost $173 \%$ and became the most open economy among the V4 countries. Figure 1 also shows very similar development in the degree of openness of the Czech Republic and Slovakia.

Figure 1 Openness of the V4 economies (share of total turnover of foreign trade in GDP in \%)

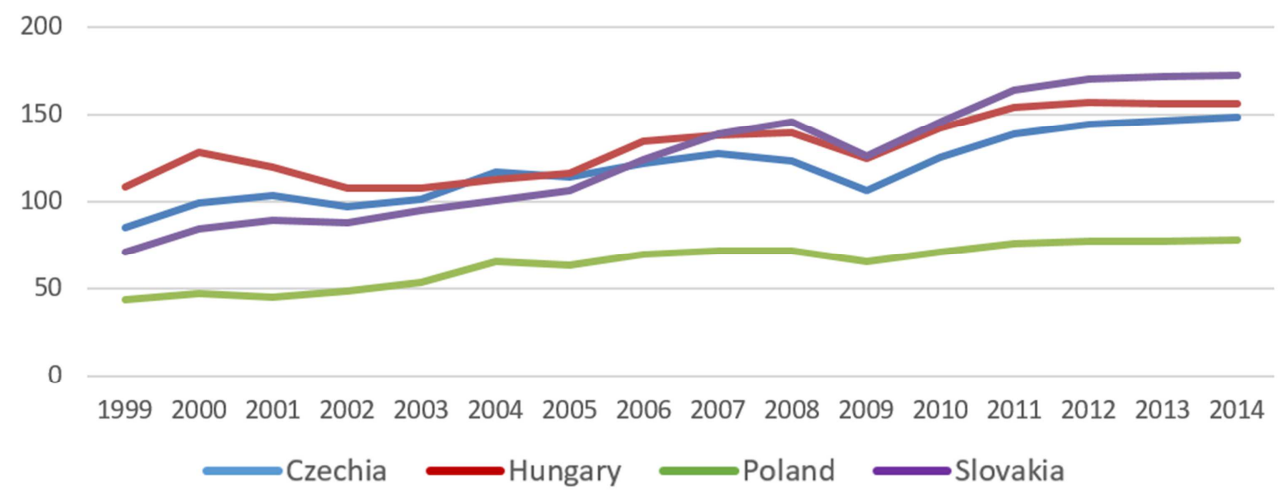

Source: Author's work based on OECD data 
This development is likely given by the common characteristics of these economies. The indicator of openness of the Czech economy reached $85 \%$ at the beginning of the period; it increased to nearly $150 \%$ in 2014 . The dynamics of the growth rate of openness were variable during the sample period, but a significant increase can be seen in all cases in 2004, which is most likely related to the accession to the EU. There can also be observed a common significant decline in 2009 due to the economic crisis trespassing the region of Central Europe. A vastly different degree of openness is typical of Poland, which despite doubling of this ratio during the years, is still beyond the average of the other analyzed countries.

Poland is different from the other countries also in other aspects. As is shown in Figure 2, a deficit in the trade balance of all V4 countries is observed at the beginning of the period, but deficit in Poland is the most significant. Although the deficits are gradually corrected in each country, Poland's reduction is the highest one. Slovakia has the initial deficit mostly due to the lack of industrial restructuring and subsequent difficulties asserting its companies to foreign markets. There was a price reduction of imports as a result of the effective appreciation of the Slovak koruna and a further loss of the price competitiveness of Slovak exports. Another negative factor was represented by one of the highest unit labor costs among transition economies. Furthermore, the government policy in the area of foreign loans and government guarantees was aimed primarily to support the infrastructure with a minimal impact on the export performance of the Slovak economy. Thus, the return of foreign exchange obtained through foreign loans became more difficult. The improvement in the trade balance in Figure 2 can be caused by the change towards the investmentfriendly economic policies and usage of pro-export tools.

Figure 2 Development of the V4 trade balances (the share of total exports in total imports)

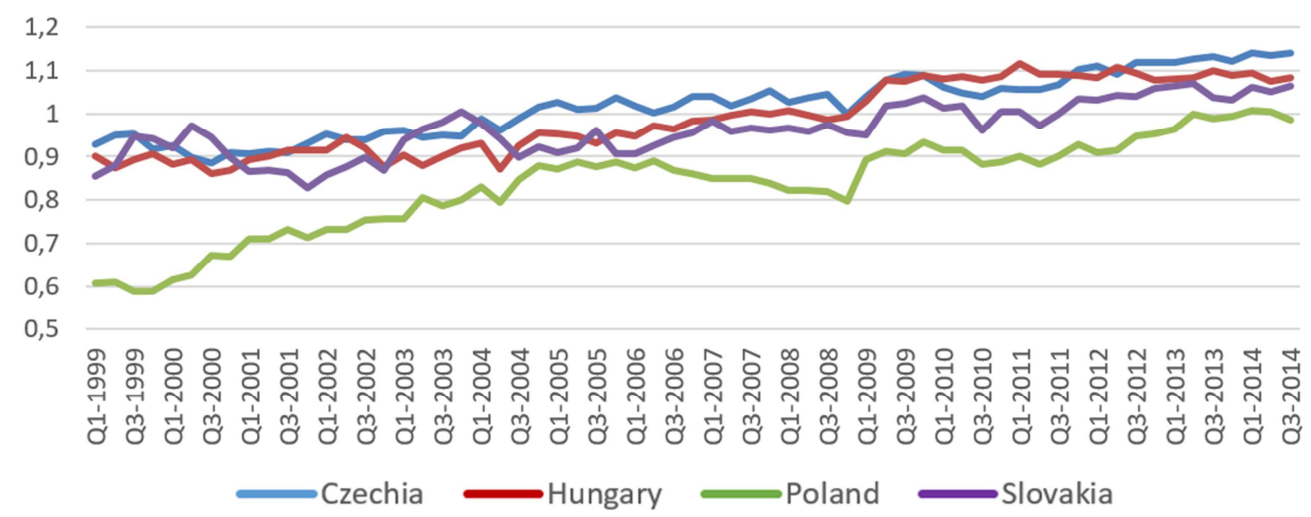

Source: Author's work based on OECD data

Changes of openness of the Czech economy have been related to the development of both export and import. They reflected the overall economic situation in the country and in the major trading partner economies. It can be concluded that the increase in the level of openness of the Czech economy in the years 1999-2014 was mainly 
driven by the export growth, which was generally higher than the growth rate of imports. Increase in Czechia's openness was caused by the trade policy, by improving the competitiveness of Czech products in world markets and by the growth of intraindustry trade occurred from the second half of the $1990 \mathrm{~s}$ in relation to the placement of foreign direct investment in the Czech Republic. Foreign direct investment also helped carry out the necessary structural changes in the economy. Foreign capital in production helped to change the structure of industrial production to manufacture products with higher added value and product's sales in new markets. This reflected in its positive trade balance.

Both components of foreign trade were increasing due to foreign trade policy in Hungary during the sample period, but import volumes exceeded the amount of exports in value terms, which resulted in a negative trade balance. However, trade balance has been improving on average. According to Fojtíková (2011), this improvement is caused by a favorable economic situation in Hungary as well as in other EU countries which became Hungary's main trading partners during the transition period. Exports were driven by the machinery and transport equipment as well as by the capital-intensive production.

\section{Territorial Structure of V4 Foreign Trade}

Figure 3 shows the territorial structure of major trading partners of the V4 countries (selected countries represent more than $50 \%$ of their total foreign trade turnover).

Figure 3 Territorial structure of V4 foreign trade (share of total foreign trade of the country in \%)

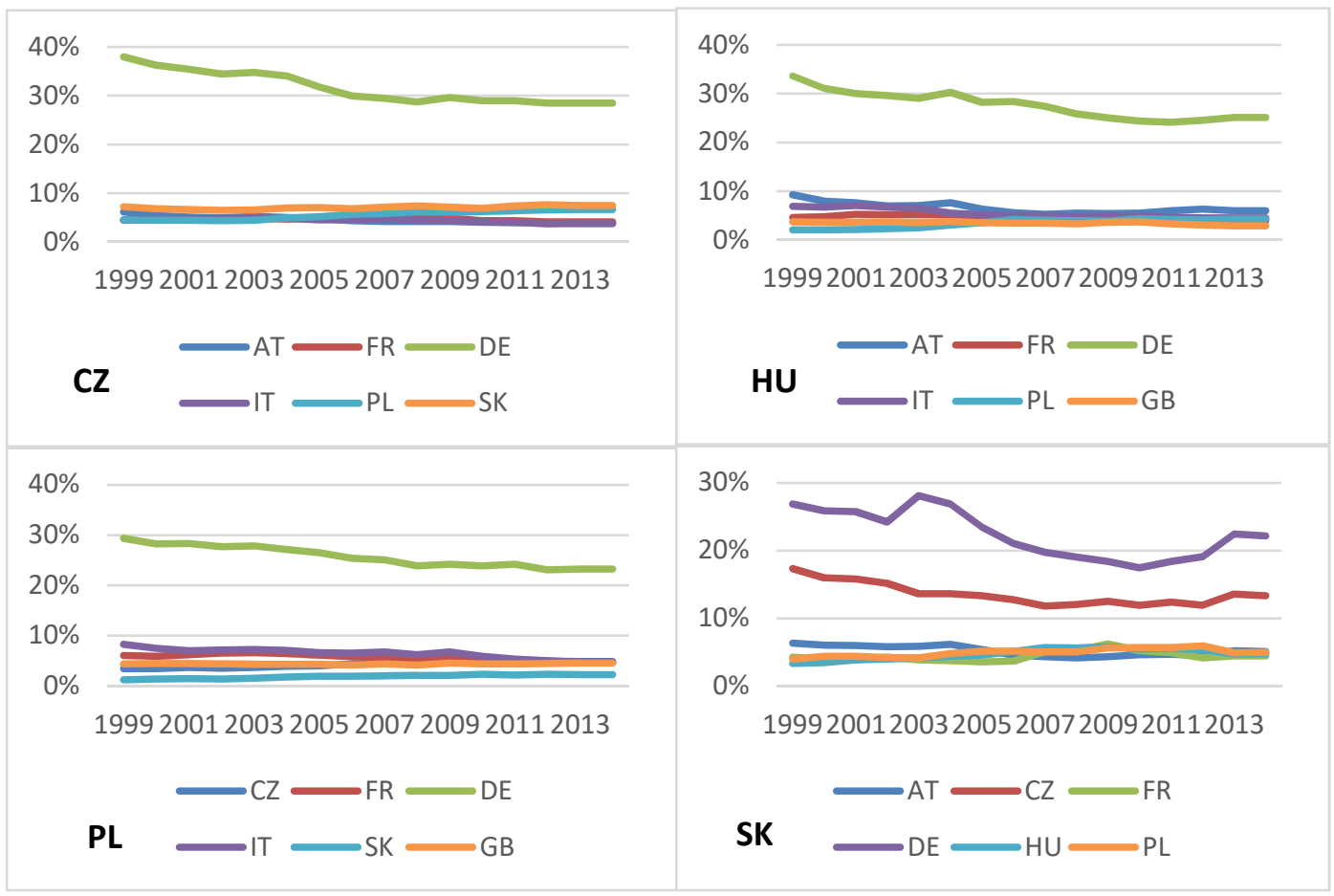

Source: Author's work based on OECD data 
The similarity of foreign trade pattern is evident. Regional similarity and connection of producers as well as consumer behavior result in their mutual trade even. Approximately a quarter of V4 foreign trade is done with Germany as the trend determining economy and the most important foreign market for Central European countries. The long-term economic ties between Czechia and Slovakia are also visible in Figure 3. In general, thanks to barrier-free trade within EU, the V4 countries do the foreign trade mostly with other member states (almost $80 \%$ on average). Non-EU countries have a lower share in V4 foreign trade focused predominantly on goods as cheaper equivalents (USA, China), goods from strategic partners (Russia) or domestic country of foreign direct investment (South Korea).

\section{Commodity Structure of V4 Foreign Trade}

Figure 4 shows the visible dominance of machinery and transport equipment in V4 foreign trade. These trade flows represent $47 \%$ share in Czechia, $57 \%$ share in Hungary, $37 \%$ share in Poland and $44 \%$ share in Slovakia on average during the sample period. Manufactured goods with $20 \%$ share (13\% for Hungary) are the second major product categories in terms of foreign trade. Another $10 \%$ share falls to miscellaneous manufactured articles. These characteristics clearly determine the V4 foreign trade.

Figure 4 Commodity structure of V4 foreign trade (share of individual product trade of the total foreign trade in \%)

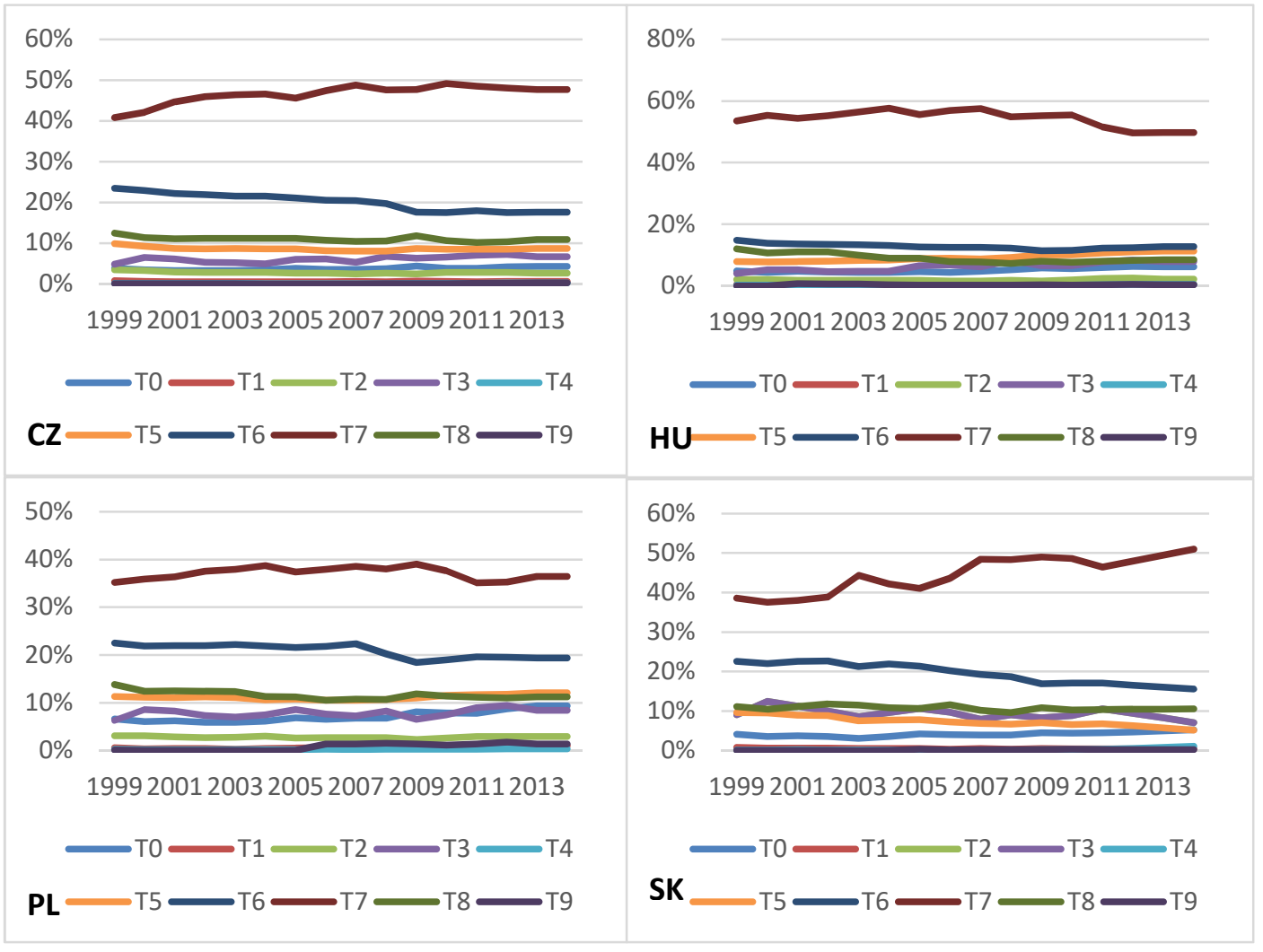

Source: Author's work based on OECD data 


\subsection{Development of Exchange Rates in V4 Countries}

Development of exchange rate policies of V4 economies can be also considered one of the key attributes associated with the fundamental economic and political decisions after the start of the transformation process in 1989. Mirdala (2011) notes that despite specific individual features of this process, we can mention several similar facts. The common characteristics can be illustrated by the starting position after 1989; the development of basic macroeconomic proportions during the first decade of the transition process; and the same goal, which was the accession to the EU and the subsequent adoption of the euro (EUR). Ongoing specific processes during the transition period were associated with significant economic transformation, development and deregulation of the various sub-markets and changing of relative prices patterns. These processes fundamentally determine the terms and conditions of formation of long-term trends influencing the competitiveness of V4 foreign trade.

V4 countries applied the system of fixed exchange rates at the beginning of the transformation process. This instrument was considered the most effective tool in fighting against inflation and reducing the disinflation process costs. This approach is based on the fact that most transition countries show signs of small open economies. One of the main factors influencing the selection of an appropriate strategy for the exchange rate system in the V4 countries at the beginning was the need for a stable macroeconomic environment, accessibility and volume of foreign exchange assets (reserves) and the overall level of economic openness. Later changes of the exchange rate system were affected by the ability of these countries to manage economic activities conditioned by the international capital movements and in practical terms, they were affected by institutional factors related to their future accession to the European Exchange Rate Mechanism II (ERM II). Mirdala (2011) states that after the completion of the EU accession process in 2004, these countries achieved greater stability of exchange rates of their national currencies in relation to the euro. EUR has played an important role in the exchange rate policies of the V4 countries since its inception - in the form of a nominal anchor, reference currency and as the main indicator of the exchange rate development.

Figure 5 Development of V4 REER

(Index with 18 Major Trading Partners, CPI Deflator)

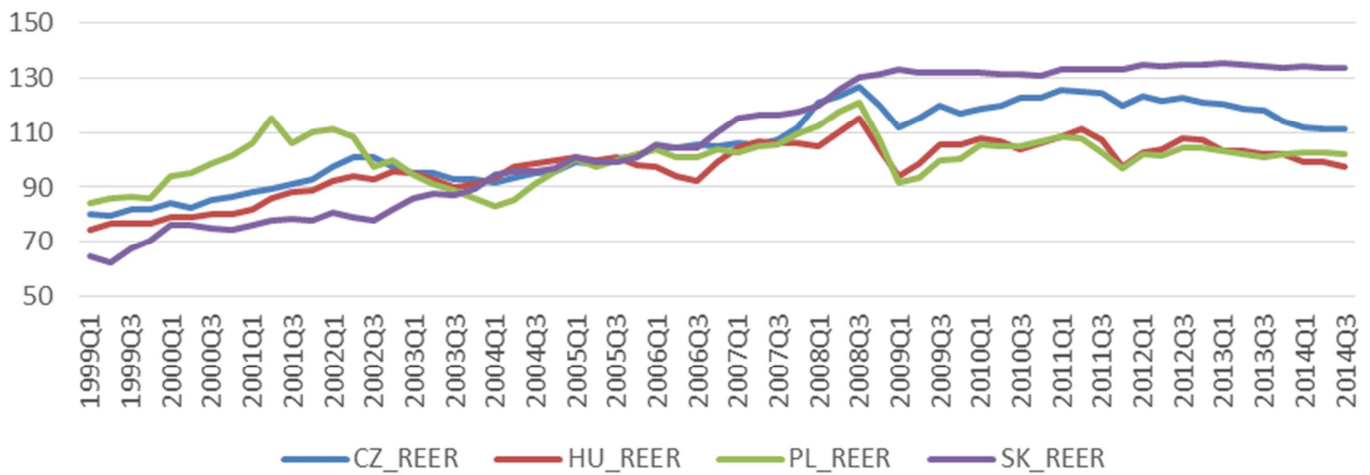

Source: Author's work based on Eurostat data 
Czechia and Slovakia applied the managed float system during the whole sample period. Poland shifted from fixed exchange rate parities to free floating in April 2000. Hungary first expanded the oscillating band to $\pm 15 \%$ in the fixation of the Hungarian forint (HUF) to EUR in May 2001 and then adopted the managed float system with EUR reference currency. The real effective exchange rate (REER) can be seen in Figure 5 . The biggest changes in the sample period were reported for the Slovak koruna (SKK), which entered the ERM II system with central rate set at 38.4550 SKK/EUR in November 2005. The central parity of the Slovak koruna was revalued to 35.4424 SKK/EUR in March 2007 and to 30.1260 SKK/EUR in May 2008. In 2009, Slovakia adopted the EUR currency as the first V4 country. Mirdala (2011) states that exchange rate policies of the Czech Republic, Hungary and Poland are fully compliant with the assumptions to enter the ERM II system. The decision on the accession of these countries' currencies into ERM II can therefore be considered rather a question of an overall ability for EMU (European Monetary Union) accession and the ability to sustainably fulfill the convergence criteria. The last financial crisis might be one of the reasons for considerations about the national currencies of the remaining V4 countries to enter the ERM II . Exchange rate instability and currencies' depreciation against the euro was particularly evident during the first half of the year 2009. Moreover, Czech koruna vis-à-vis the euro has been adopted by the Czech National Bank as a regular monetary policy tool since the third quarter of 2013.

To summarize, the exchange rate policy of HUF and PLN (Polish zloty) applied until 1999 did not lead to the reduction of deficits of their trade balances. The following shift of PLN to floating regime allowed Poland to reduce real appreciation of PLN without a significant impact on the trade balance. Fixation of HUF to EUR caused significant real appreciation of HUF followed by the worsening of the trade deficit. The real currency appreciation in the Czech Republic and Slovakia was related to the high real economic growth after 2000, enabling these countries to maintain a competitive position in international markets. Currency interventions of the Czech National Bank play an important role in the improvement of the Czechia's trade balance. Contrary to Czechia, the Euro adoption does not allow for a more significant improvement of the trade balance in Slovakia.

\section{Empirical Estimation and Results}

This study employs a reduced form of trade balance model by Rose and Yellen (1989) to analyze the long-run effects of changes in exchange rate on the trade balance. The trade balance is expressed as a function of exchange rate and the domestic and foreign income. The Johansen cointegration procedure is applied to avoid the main criticism of early studies, whose results could suffer from spurious regression problem because of non-stationary data. For empirical analysis of tested trade flows, the model is specified as follows (1):

$$
\ln T B_{p, t}=\alpha+\beta \ln Y_{d, t}+\chi \ln Y_{f, t}+\lambda \ln E R_{f, t}+\varepsilon_{t}
$$

The variable of trade balance $T B$ is calculated as a ratio of export to import in bilateral flows with key trading partners. The paper further assumes that foreign 
exchange rates can affect the individual product-level trade balances in different way. The analysis therefore constructs variable $T B_{p}$ as a share of export to import in each SITC (Standard International Trade Classification) product category in tested bilateral trading flows. Incomes of individual countries $Y_{d}$ for domestic country $d$ and $Y_{f}$ for foreign trading partner $f$ are represented by GDP in current prices, and are converted into an index form, to calculate the unitless value. Exchange rates $E R$ are calculated as a quarterly average of monthly nominal exchange rate in direct quotations. The exchange rate is defined in a manner that an increase reflects a depreciation of the domestic currency. $\varepsilon$ represents an error term. Since an increase in foreign income $Y_{f}$ is expected to increase the exports to respective country, an estimate of $Y$ is expected to be positive. Contrary, since an increase in domestic income $Y_{d}$ is assumed to increase the imports, an estimate of $\beta$ is expected to be negative. Finally, the parameter $\lambda$ is expected to be positive as the trade balance of respective industry should improve due to domestic currency depreciation. All time series used for estimation are in the quarterly frequency and cover the period from 1999:1 to 2014:3. Estimated product groups representing the commodity structure of trade in selected sectors are determined on the basis of SITC classification:

- TT: Total trade;

- T0: Food and live animals;

- T1: Beverages and tobacco;

- T2: Crude materials, inedible, except fuels;

- T3: Mineral fuels, lubricants and related materials;

- T4: Animal and vegetable oils, fats and waxes;

- T5: Chemicals and related products;

- T6: Manufactured goods;

- T7: Machinery and transport equipment;

- T8: Miscellaneous manufactured articles;

- T9: Commodities and transactions not classified elsewhere in the SITC.

In the case of Slovakia, the time series of trade flows with AT, DE and FR are shortened to the period 1999:Q1 - 2008:Q4, due to the adoption of the euro as the official currency in 2009. Other data cover the period 1999:Q1 - 2014:Q3 and mean 63 observations on a quarterly frequency. All time series are modified by logarithmic transformation. ADF (augmented Dickey-Fuller test) stationarity test results confirm the integration of $\mathrm{I}(1)$ for all variables, which is the assumption for the Johansen cointegration analysis employed to test the long-term relationships. The presence of long-term bonds between the variables is assessed on the basis of Trace and Maximum eigenvalue test.

\subsection{Testing of Lags and Cointegration Equations}

The lag structure of variables in the model has a significant impact on the conclusions adopted on the basis of the model. Lags in empirical literature are usually centered around two years. In many countries, however, this period varies across trading partners because of the different nature and flexibility of traded goods and time needed for consumers' adaptation (Auboin and Ruta, 2013). The optimal lags in this paper are determined by maximizing the Schwarz information criterion. Values can be seen in Tables 1-4. One lag means delay a of one quarter. These tables also show 
the results of Johansen cointegration test on the number of existing cointegration vectors $(r)$. The existing long-term relationship between variables is proved if $r \neq 0$.

Table 1 Number of lags and cointegration equations for Czechia

\begin{tabular}{l|cl|cl|cc|cc|cc|cc}
\hline & $\begin{array}{c}\text { AT } \\
\text { lag }\end{array}$ & $\boldsymbol{r}$ & $\begin{array}{c}\text { DE } \\
\text { lag }\end{array}$ & $\boldsymbol{r}$ & $\begin{array}{c}\text { FR } \\
\text { lag }\end{array}$ & $\boldsymbol{r}$ & $\begin{array}{c}\text { IT } \\
\text { lag }\end{array}$ & $\boldsymbol{r}$ & $\begin{array}{c}\text { PL } \\
\text { lag }\end{array}$ & $\boldsymbol{r}$ & $\begin{array}{c}\text { SK } \\
\text { lag }\end{array}$ & $\boldsymbol{r}$ \\
\hline TT & 4 & 1 & 2 & 1 & 2 & 1 & 4 & 1 & 2 & 1 & 2 & 1 \\
T0 & 4 & 1 & 2 & 1 & 2 & 1 & 2 & 2 & 2 & 2 & 2 & 1 \\
T1 & 4 & 1 & 2 & 0 & 2 & 1 & 2 & 0 & 2 & 1 & 2 & 1 \\
T2 & 4 & 1 & 2 & 1 & 3 & 1 & 2 & 1 & 2 & 2 & 2 & 1 \\
T3 & 4 & 0 & 2 & 1 & 4 & 1 & 2 & 1 & 2 & 1 & 2 & 1 \\
T4 & 4 & 0 & 2 & 0 & 4 & 0 & 2 & 0 & 2 & 0 & 2 & 0 \\
T5 & 4 & 1 & 4 & 1 & 5 & 1 & 2 & 1 & 3 & 1 & 5 & 1 \\
T6 & 5 & 0 & 4 & 1 & 9 & 1 & 5 & 0 & 2 & 1 & 5 & 1 \\
T7 & 5 & 1 & 4 & 1 & 9 & 1 & 9 & 1 & 3 & 1 & 5 & 1 \\
T8 & 5 & 1 & 9 & 1 & 9 & 0 & 9 & 1 & 4 & 1 & 9 & 1 \\
T9 & 5 & 0 & 4 & 0 & 5 & 0 & 5 & 0 & 4 & 0 & 4 & 0 \\
\hline
\end{tabular}

Source: Author's calculations

The empirical estimates of the effects of the level of foreign exchange rates on the trade balance for the Czech Republic is provided for trading partners AT, DE, FR, IT, $\mathrm{PL}$ and SK. The sum of their average shares in the total foreign trade is $58 \%$ in the sample period and results can be seen in Table 1 . The optimal lags calculated for each trading partner in various product categories show that the average delay in product groups T0 to T4 is lower than in the other categories tested. This confirms the assumption of Auboin and Ruta (2013) that the lower lags in these product categories are affected by the higher substituting. Johansen cointegration test results on the number of existing co-integration equations say that the aggregate bilateral trade balances $\pi$ are in the long-term relationship with exchange rate movements, but exceptions can be found at the product level. No cointegration vector was estimated for product categories with animal and vegetable oils, fats, waxes and too heterogeneous category of commodities and transactions not classified elsewhere. Animal and vegetable oils, fats and waxes belong to the product category characterized by a substantially smaller share in the total foreign trade. For the Czech Republic it is less than $0.1 \%$ in the sample period. The territorial structure shows that a lower amount of long-term relationships is estimated in trade with AT and IT. In the case of AT, it means $31.3 \%$ of product categories bilaterally traded without long-term relationship. In the case of IT, it is $27.3 \%$ of bilateral foreign trade. In other trading flows there is no long-term cointegration proved only for less than $1 \%$ foreign trade. Therefore, it can be concluded that the individual trade balances are characterized by a long-term joint development of Czech GDP, GDP of trading partners, as well as a bilateral exchange rate.

The empirical estimates for Hungary (Table 2) were provided for trading partners $C Z$, $\mathrm{DE}, \mathrm{FR}, \mathrm{GB}, \mathrm{IT}$ and SK. The sum of their average shares in the total foreign trade is $51 \%$ in the period. The optimum lag for AT is approximately one year in all product categories, with exception of food, live animals and crude materials. It is not possible to specify lags for Hungary by the commodity structure, but we can observe lags 
higher than five quarters only in categories of manufactured goods and miscellaneous manufactured articles. Johansen cointegration tests for Hungary show a significantly lower number of cointegration vectors in comparison to the Czech Republic.

Table 2 Number of lags and cointegration equations for Hungary

\begin{tabular}{l|ll|ll|ll|ll|ll|ll}
\hline & $\begin{array}{c}\text { AT } \\
\text { lag }\end{array}$ & $\boldsymbol{r}$ & $\begin{array}{c}\text { DE } \\
\text { lag }\end{array}$ & $\boldsymbol{r}$ & $\begin{array}{c}\text { FR } \\
\text { lag }\end{array}$ & $\boldsymbol{r}$ & $\begin{array}{c}\text { GB } \\
\text { lag }\end{array}$ & $\boldsymbol{r}$ & $\begin{array}{c}\text { IT } \\
\text { lag }\end{array}$ & $\boldsymbol{r}$ & $\begin{array}{c}\text { PL } \\
\text { lag }\end{array}$ & $\boldsymbol{r}$ \\
\hline TT & 4 & 1 & 9 & 1 & 3 & 1 & 1 & 1 & 5 & 1 & 2 & 1 \\
T0 & 2 & 0 & 4 & 2 & 2 & 1 & 2 & 1 & 4 & 1 & 4 & 1 \\
T1 & 4 & 1 & 5 & 1 & 2 & 1 & 4 & 0 & 4 & 1 & 4 & 1 \\
T2 & 2 & 1 & 5 & 0 & 4 & 0 & 4 & 0 & 4 & 1 & 2 & 2 \\
T3 & 4 & 1 & 5 & 0 & 4 & 0 & 4 & 0 & 4 & 0 & 2 & 0 \\
T4 & 5 & 0 & 5 & 2 & 5 & 0 & 4 & 0 & 4 & 0 & 4 & 0 \\
T5 & 4 & 1 & 4 & 1 & 3 & 1 & 4 & 0 & 6 & 1 & 2 & 0 \\
T6 & 4 & 1 & 8 & 2 & 5 & 1 & 9 & 0 & 5 & 2 & 4 & 1 \\
T7 & 5 & 0 & 8 & 2 & 3 & 1 & 1 & 1 & 7 & 2 & 5 & 2 \\
T8 & 4 & 1 & 9 & 1 & 4 & 1 & 8 & 1 & 9 & 0 & 6 & 2 \\
T9 & 5 & 0 & 4 & 0 & 5 & 0 & 4 & 0 & 4 & 0 & 2 & 0 \\
\hline
\end{tabular}

Source: Author's calculations

Despite the long-term equilibrium of exchange rates with the total bilateral trade balances, disaggregating to the partial trade balances shows significantly different results. GB manifests a long-term relationship only in three partial trade balances. However, the overall bilateral cointegration is probably given by the dominance of shares of these three foreign trade components (machinery and transport equipment - 66\%; miscellaneous manufactured articles - 8\%; food and live animals - 3\%). There were estimated more cointegration equations in trade flows with AT, but sum of the product-level trade balances is only $52 \%$ of total bilateral foreign trade. No long-term relationship was proved for $20.6 \%$ of foreign trade realized between Hungary and PL and $16.3 \%$ between Hungary and IT. In case of DE and FR can be observed statistically significant tendency to common movement with exchange rates in case of more than $95 \%$ share on total bilateral foreign trade.

Table 3 Number of lags and cointegration equations for Poland

\begin{tabular}{l|ll|ll|ll|ll|ll|ll}
\hline & $\begin{array}{l}\text { CZ } \\
\text { lag }\end{array}$ & $\boldsymbol{r}$ & $\begin{array}{l}\text { DE } \\
\text { lag }\end{array}$ & $\boldsymbol{r}$ & $\begin{array}{l}\text { FR } \\
\text { lag }\end{array}$ & $\boldsymbol{r}$ & $\begin{array}{l}\text { GB } \\
\text { lag }\end{array}$ & $\boldsymbol{r}$ & $\begin{array}{l}\text { IT } \\
\text { lag }\end{array}$ & $\boldsymbol{r}$ & $\begin{array}{l}\text { SK } \\
\text { lag }\end{array}$ & $\boldsymbol{r}$ \\
\hline TT & 4 & 1 & 2 & 1 & 4 & 1 & 4 & 0 & 4 & 1 & 2 & 2 \\
T0 & 4 & 1 & 2 & 1 & 2 & 0 & 4 & 2 & 2 & 1 & 2 & 1 \\
T1 & 4 & 1 & 2 & 1 & 2 & 1 & 5 & 0 & 2 & 1 & 2 & 1 \\
T2 & 4 & 1 & 2 & 1 & 4 & 0 & 8 & 1 & 2 & 1 & 2 & 0 \\
T3 & 4 & 1 & 2 & 1 & 4 & 0 & 5 & 0 & 2 & 0 & 2 & 0 \\
T4 & 4 & 0 & 5 & 0 & 4 & 0 & 5 & 0 & 2 & 0 & 5 & 0 \\
T5 & 4 & 2 & 4 & 1 & 4 & 2 & 4 & 0 & 2 & 1 & 2 & 1 \\
T6 & 4 & 1 & 5 & 1 & 9 & 1 & 9 & 1 & 9 & 1 & 9 & 1 \\
T7 & 4 & 1 & 6 & 1 & 9 & 1 & 9 & 1 & 9 & 1 & 9 & 1 \\
T8 & 6 & 1 & 6 & 1 & 9 & 1 & 8 & 2 & 9 & 1 & 9 & 1 \\
T9 & 5 & 0 & 4 & 0 & 5 & 0 & 5 & 0 & 4 & 0 & 2 & 0 \\
\hline
\end{tabular}

Source: Author's calculations 
The empirical estimates for Poland are for trading partners CZ, DE, FR, GB, IT and SK and are presented in Table 3 . The average share of selected trading partners in the total foreign trade is $52 \%$ in the sample period. The optimum lags calculated for each trading partner in individual product categories show higher lags in trade with manufactured goods, machinery and transport equipment and miscellaneous manufactured articles. These results are similar to the case of Czechia. Results of Johansen cointegration test show that aggregate bilateral trade balances are in longterm equilibrium for all trading partners except GB. GB represents on average a $5 \%$ share in the total foreign trade of Poland and its share of cointegrated product categories represents $48.6 \%$ of total trade. This is likely to translate into overall relationship without a long-term equilibrium. The lower number of cointegration vector was also demonstrated in the case of $F R$, where up to 5 estimated trade balances are not in the long-term relationship with GDPs of Poland and FR and their bilateral exchange rate. However, this trade represents only $8 \%$ of the total foreign trade between Poland and FR. Other estimated trading partners are characterized by long-term bond in product categories representing more than $95 \%$ of the trades. The cointegration in the case of trade with animal and vegetable oils, fats, waxes and residual commodities and transactions was not confirmed for Poland.

Table 4 Number of lags and cointegration equations for Slovakia

\begin{tabular}{l|ll|ll|ll|ll|ll|ll}
\hline & $\begin{array}{l}\text { AT } \\
\text { lag }\end{array}$ & $\boldsymbol{r}$ & $\begin{array}{l}\text { CZ } \\
\text { lag }\end{array}$ & $\boldsymbol{r}$ & $\begin{array}{l}\text { DE } \\
\text { lag }\end{array}$ & $\boldsymbol{r}$ & $\begin{array}{l}\text { FR } \\
\text { lag }\end{array}$ & $\boldsymbol{r}$ & $\begin{array}{l}\text { HU } \\
\text { lag }\end{array}$ & $\boldsymbol{r}$ & $\begin{array}{l}\text { PL } \\
\text { lag }\end{array}$ & $\boldsymbol{r}$ \\
\hline TT & 4 & 1 & 2 & 1 & 2 & 1 & 4 & 1 & 2 & 1 & 4 & 1 \\
T0 & 4 & 1 & 2 & 1 & 2 & 1 & 2 & 2 & 2 & 2 & 2 & 1 \\
T1 & 4 & 1 & 2 & 1 & 2 & 1 & 2 & 1 & 2 & 1 & 2 & 1 \\
T2 & 4 & 1 & 2 & 1 & 2 & 1 & 2 & 1 & 2 & 1 & 2 & 1 \\
T3 & 4 & 1 & 2 & 1 & 4 & 1 & 2 & 1 & 2 & 1 & 2 & 1 \\
T4 & 5 & 0 & 5 & 0 & 4 & 0 & 5 & 0 & 2 & 0 & 2 & 0 \\
T5 & 4 & 1 & 4 & 1 & 2 & 1 & 4 & 1 & 2 & 1 & 2 & 1 \\
T6 & 9 & 0 & 8 & 1 & 9 & 1 & 9 & 0 & 8 & 1 & 9 & 2 \\
T7 & 9 & 1 & 9 & 2 & 9 & 1 & 9 & 1 & 8 & 1 & 9 & 2 \\
T8 & 9 & 1 & 9 & 1 & 9 & 1 & 9 & 1 & 8 & 1 & 9 & 1 \\
T9 & 5 & 0 & 4 & 0 & 5 & 0 & 9 & 0 & 4 & 0 & 5 & 0 \\
\hline
\end{tabular}

Source: Author's calculations

Empirical estimates for Slovakia were provided for trade flows with partners AT, CZ, $\mathrm{DE}, \mathrm{FR}, \mathrm{HU}$ and $\mathrm{PL}$ (Table 4). Their average shares in the total foreign trade of Slovakia are $55 \%$ in the sample period. Trade with manufactured goods, machinery and transport equipment and miscellaneous manufactured articles is also in this case characterized by higher lags. Johansen cointegration test results suggest that all aggregate bilateral trade balances are in the long-term relationship. However, we can find exceptions at the product-level. Similar to Hungary and Poland, there is no longterm relationship between exchange rates and Slovakia's trade balances of animal and vegetable oils, fats, waxes and residual commodities. A lower amount of longterm relationships was demonstrated in partial trade balances with AT ( $32 \%$ of the total trade between countries). 


\subsection{Testing of Long-term Effects}

Estimated coefficients of long-term effects of individual explanatory variables included in the model for bilateral and product-level trade balances with proven long-term tendency for joint movement are shown in Table 5-8.

Table 5 Estimated coefficients of long-term effects for Czechia

\begin{tabular}{|c|c|c|c|c|c|c|c|c|c|c|c|c|c|c|c|c|c|c|}
\hline & & AT & & & DE & & & FR & & & IT & & & PL & & & SK & \\
\hline & $Y d$ & $\boldsymbol{Y} \boldsymbol{f}$ & $E R$ & $Y d$ & $Y f$ & $E R$ & $Y d$ & $Y f$ & $E R$ & $Y d$ & $\boldsymbol{Y f}$ & $E R$ & $Y d$ & $Y f$ & $E R$ & $Y d$ & $\boldsymbol{Y f}$ & $E R$ \\
\hline TT & -5.32 & 1.47 & -1.27 & 0.42 & 0.86 & 0.20 & 0.38 & 1.34 & -0.23 & 0.21 & 1.53 & 1.27 & 1.29 & 1.02 & 3.55 & -3.74 & 3.10 & -0.16 \\
\hline T0 & 8.36 & 0.47 & 2.37 & -4.14 & 2.05 & -1.10 & -1.62 & 3.79 & -1.97 & & 2.75 & 1.41 & & -0.39 & 2.63 & -2.85 & 2.45 & -0.53 \\
\hline T1 & -3.24 & 6.39 & -1.51 & $\mathrm{x}$ & $x$ & $\mathrm{x}$ & -6.75 & 3.31 & 1.87 & $\mathrm{x}$ & $\mathrm{x}$ & $\mathrm{x}$ & -0.07 & 0.90 & 0.65 & 0.53 & 0.12 & 0.74 \\
\hline T2 & -8.20 & 2.71 & -1.76 & -9.74 & 2.43 & -0.27 & 1.31 & -1.27 & 0.23 & 3.75 & -1.15 & -1.26 & & 1.32 & 1.71 & 5.55 & -4.15 & 0.22 \\
\hline T3 & $\mathrm{x}$ & $\mathrm{x}$ & $\mathrm{x}$ & -10.21 & 0.06 & -0.26 & 9.31 & -2.17 & 0.11 & 7.18 & -2.36 & 1.87 & 1.04 & 0.84 & 0.56 & -8.50 & 7.62 & -0.89 \\
\hline T4 & $\mathrm{x}$ & $\mathrm{x}$ & $\mathrm{x}$ & $\mathrm{x}$ & $\mathrm{x}$ & $\mathrm{x}$ & $\mathrm{x}$ & $\mathrm{x}$ & $\mathrm{x}$ & $\mathrm{x}$ & $\mathrm{x}$ & $\mathrm{x}$ & $\mathrm{x}$ & $\mathrm{x}$ & $\mathrm{x}$ & $\mathrm{x}$ & $x$ & $\mathrm{x}$ \\
\hline T5 & -2.85 & 1.92 & -0.63 & 5.01 & -3.62 & 1.29 & -0.26 & 4.57 & 2.62 & 6.77 & -2.33 & -1.94 & -3.14 & 1.76 & -2.81 & 0.45 & -0.11 & 0.35 \\
\hline T6 & $\mathrm{x}$ & $\mathrm{x}$ & $\mathrm{x}$ & -0.00 & 1.01 & 1.59 & 0.06 & 1.69 & 2.42 & $\mathrm{x}$ & $\mathrm{x}$ & $\mathrm{x}$ & 0.93 & -0.96 & 0.22 & -1.32 & 0.94 & -0.11 \\
\hline T7 & & -5.07 & -2.17 & 0.09 & 0.51 & 0.18 & -1.27 & 4.73 & -2.67 & 6.65 & -3.10 & -2.04 & -2.49 & 0.44 & -0.82 & -6.76 & 3.64 & 0.29 \\
\hline T8 & -2.39 & 2.35 & -1.75 & -0.84 & 0.50 & -0.50 & $\mathrm{x}$ & $\mathrm{x}$ & $\mathrm{x}$ & 3.68 & 1.21 & 0.90 & 0.13 & 0.53 & 0.71 & 0.08 & -0.38 & 0.66 \\
\hline T9 & $\mathrm{x}$ & $\mathrm{x}$ & $\mathrm{x}$ & $\mathrm{x}$ & $\mathrm{x}$ & $\mathrm{x}$ & $\mathrm{x}$ & $\mathrm{x}$ & $\mathrm{x}$ & $\mathrm{x}$ & $\mathrm{x}$ & $\mathrm{x}$ & $\mathrm{x}$ & $\mathrm{x}$ & $\mathrm{x}$ & $\mathrm{x}$ & $\mathrm{x}$ & $\mathrm{x}$ \\
\hline
\end{tabular}

Source: Author's calculations

The analysis of long-term coefficients of domestic GDP for the Czech Republic shows differences across product categories and also across trading partners. Negative effects of domestic GDP on the trade balance is proved in trade with AT (except trade with food and animals $-3.5 \%$ of total trade). With the Czechia's GDP growth we can expect an increase in quantity demanded for Austrian goods in the country and thus increase in good's import, which leads to a worsening of the trade balance and is reflected in the negative effect on the total bilateral trade balance. A similar conclusion is also estimated for SK. The negative effect of Czech GDP is reflected in the total bilateral trade balance, as well as in the partial trade balances representing $74 \%$ share of bilateral trade with Slovakia. Cointegration analysis on the bilateral level proved the opposite relationship with domestic GDP for trading partners DE, FR, IT and PL. This conclusion was also confirmed by positive coefficients estimated for all cointegrated partial trade balances in the case of trade flows with IT. However, product-level analysis of other trade flows does not support the overall bilateral estimation. Consistent conclusion of bilateral and product-level trade balances in the case of DE is proven only by a $19 \%$ share in total bilateral trade with $D E, 29 \%$ with $\mathrm{NL}$ and $36 \%$ with PL. The results thus clearly show the possible bias resulting from the aggregation of data. 
Coefficient estimation of foreign partners' GDP provides clearer conclusions. All trading partners' GDP have the positive effect on total bilateral trade balances of the Czech Republic. GDP increases in foreign economies can thus be approximated with an increase in the purchasing power of foreign entities, increase in the quantity demanded for domestic goods abroad and therefore an increase in exported goods. The highest rate was demonstrated for Slovak GDP, which clearly shows the interdependence of these economies. However, there also opposite effects on the commodity level can be found. In the case of trade with AT, it is a product category representing $38 \%$ of bilateral trade, for DE category with an $8 \%$ share, for FR category with a $12 \%$ share, for SK category with a $23 \%$ share, for PL category with a $37 \%$ share and for IT category up to a $57 \%$ share in bilateral foreign trade.

The results presented in Table 5 also show that the positive effect of Czech koruna depreciation on the total bilateral trade balances can be found in trades with DE, IT and PL. Total average share of these countries in the total foreign trade turnover of the Czech Republic is $39 \%$ in the sample period. In trade flows with AT the bilateral negative coefficient is also supported by the product-level analysis (except trade with food and live animals). The effects of exchange rate on other partial trade balances are mixed. Dominance of the positive effect of Czech koruna depreciation can be observed in the cases of DE, PL and SK. These effects can be observed in $79 \%, 77 \%$ and $53 \%$ share of total bilateral trade balances. This analysis also shows that depreciation of the Czech koruna against the euro promotes exports and reduces imports in most of trade with DE on one hand, but on the other hand, the same exchange rate movement improves the trade balances with FR only for $29 \%$ share, for IT $16 \%$ share and for AT even only $4 \%$ share of tested commodity trade balances.

Table 6 Estimated coefficients of long-term effects for Hungary

\begin{tabular}{|c|c|c|c|c|c|c|c|c|c|c|c|c|c|c|c|c|c|c|}
\hline & \multicolumn{3}{|c|}{ AT } & \multicolumn{3}{|c|}{ DE } & \multicolumn{3}{|c|}{ FR } & \multicolumn{3}{|c|}{ GB } & \multicolumn{3}{|c|}{ IT } & \multicolumn{3}{|c|}{ PL } \\
\hline & $Y d$ & $\boldsymbol{Y} \boldsymbol{f}$ & $E R$ & $Y d$ & $\boldsymbol{Y f}$ & $E R$ & $Y d$ & $\boldsymbol{Y} \boldsymbol{f}$ & $E R$ & $Y d$ & $\boldsymbol{Y} \boldsymbol{f}$ & $E R$ & $Y d$ & $Y f$ & $E R$ & $Y d$ & $\boldsymbol{Y} f$ & $E R$ \\
\hline TT & 2.41 & -7.37 & 8.89 & -0.63 & 0.91 & -0.09 & -10.60 & 9.13 & -1.11 & -0.52 & 1.44 & -0.17 & -2.58 & 8.13 & -1.18 & 0.16 & -0.49 & 1.75 \\
\hline TO & $\mathrm{x}$ & $\mathrm{x}$ & $\mathrm{x}$ & & 1.84 & 1.49 & -4.42 & 6.18 & -4.86 & 7.19 & -11.44 & 1.23 & -2.69 & 6.42 & 1.04 & -1.11 & 0.10 & 1.42 \\
\hline T1 & 1.48 & -2.06 & 2.94 & 2.74 & 8.26 & -0.24 & -6.65 & 2.07 & 0.05 & $\mathrm{x}$ & $\mathrm{x}$ & $\mathrm{x}$ & -5.58 & 10.37 & 1.19 & -1.91 & 3.01 & -1.50 \\
\hline T2 & -0.96 & 4.56 & -0.19 & $x$ & $\mathrm{x}$ & $\mathrm{x}$ & $\mathrm{x}$ & $\mathrm{x}$ & $\mathrm{x}$ & $\mathrm{x}$ & $\mathrm{x}$ & $\mathrm{x}$ & 0.42 & -0.24 & 1.89 & & 1.46 & -1.50 \\
\hline T3 & 2.99 & -10.32 & 9.13 & $\mathrm{x}$ & $\mathrm{x}$ & $\mathrm{x}$ & $\mathrm{x}$ & $\mathrm{x}$ & $\mathrm{x}$ & $\mathrm{x}$ & $\mathrm{x}$ & $\mathrm{x}$ & $\mathrm{x}$ & $\mathrm{x}$ & $\mathrm{x}$ & $\mathrm{x}$ & $\mathrm{x}$ & $\mathrm{x}$ \\
\hline T4 & $\mathrm{x}$ & $\mathrm{x}$ & $\mathrm{x}$ & & 3.62 & 4.19 & $\mathrm{x}$ & $\mathrm{x}$ & $\mathrm{x}$ & $\mathrm{x}$ & $\mathrm{x}$ & $\mathrm{x}$ & $\mathrm{x}$ & $\mathrm{x}$ & $\mathrm{x}$ & $\mathrm{x}$ & $\mathrm{x}$ & $\mathrm{x}$ \\
\hline T5 & -0.00 & -0.66 & 2.79 & -2.89 & 1.12 & -0.83 & -0.30 & 6.40 & -1.14 & $\mathrm{x}$ & $\mathrm{x}$ & $\mathrm{x}$ & -0.08 & 6.76 & -0.91 & $\mathrm{x}$ & $\mathrm{x}$ & $\mathrm{x}$ \\
\hline T6 & -0.14 & -1.86 & 0.73 & -4.65 & 12.81 & 1.86 & 2.14 & -5.67 & 0.79 & $\mathrm{x}$ & $\mathrm{x}$ & $\mathrm{x}$ & & -0.98 & 1.23 & -0.12 & 0.08 & 0.89 \\
\hline T7 & $\mathrm{x}$ & $\mathrm{x}$ & $\mathrm{x}$ & & 0.17 & 0.47 & -7.70 & 4.94 & -1.64 & -1.17 & 2.27 & -0.39 & & 2.20 & -1.91 & & -2.10 & 1.78 \\
\hline T8 & 0.24 & -2.24 & 0.29 & -2.32 & 2.34 & -2.84 & 6.18 & 2.23 & -2.07 & 8.61 & 4.60 & -1.75 & $\mathrm{x}$ & $\mathrm{x}$ & $\mathrm{x}$ & & -0.47 & 0.04 \\
\hline T9 & $\mathrm{x}$ & $\mathrm{x}$ & $\mathrm{x}$ & $\mathrm{x}$ & $\mathrm{x}$ & $\mathrm{x}$ & $\mathrm{x}$ & $\mathrm{x}$ & $\mathrm{x}$ & $\mathrm{x}$ & $\mathrm{x}$ & $\mathrm{x}$ & $\mathrm{x}$ & $\mathrm{x}$ & $\mathrm{x}$ & $\mathrm{x}$ & $\mathrm{x}$ & $\mathrm{x}$ \\
\hline
\end{tabular}

Source: Author's calculations 
The assumption of the negative impact of domestic GDP growth on the export to import ratio can be clearly confirmed for Hungary's tested trade balances neither (Table 6). This fact is evident in the estimated positive coefficients for the third and fifth most important trading partners - AT and PL. The highest degree of conformity of results in terms of territorial distribution is confirmed for $F R$, where the expected effect can be observed at bilateral level and at the $76 \%$ share of the total partial trade balances. On the other hand, significantly different results between the bilateral-level and product-level analyses are seen in trade balance with PL. At the product level, we can see the uniformity of results in product category of chemicals and related products. These products represent $9 \%$ of the total foreign trade of Hungary and an $11 \%$ average share of bilateral trade flows examined.

The expected positive effect of GDPs growth in trading partners' economies is clearly demonstrated in trade balance with the major trading partner - DE. German economic growth probably translates into increased demand for Hungarian products, and thus leads to an improvement of the individual commodity trade balances. The same direction of effects is also reflected in trade with $F R$, except the product category with machinery and transport equipment ( $9 \%$ of bilateral trade). Although the trade balances with the GB show a tendency for long-term joint motion only in a minor number of product categories, increasing of its GDP would be linked to the improvement in the ratio of Hungarian more than $74 \%$ share of their bilateral trade. Parameter shows considerable inconsistency between product and bilateral analyzes and points to a bias resulting from the aggregation of data also in the case of PL.

Although the results of the analysis indicate that the growth of Austrian GDP probably does not lead to an improvement in the trade balance with AT, the improvement can be led by the depreciation of the Hungarian forint against the euro. This depreciation seems to be an effective tool even in the case of improvement of product trade balances that cumulated represent an $80 \%$ of trade with DE on one hand, but only $33 \%$ of trade with IT and $12 \%$ of trade with FR on the other hand. The results of the paper suggest that an increase in the ratio of exports over imports with the PL can be reached through the depreciation of the Hungarian forint against the Polish zloty in both - total bilateral as well as product categories representing $77 \%$ of their mutual trade flows. Long-term effects analysis further showed that the depreciation of the Hungarian forint is associated with improvement in all trade balances of machinery and transport equipment (13\% of the total Hungarian foreign trade).

Table 7 shows that even Poland's GDP (as the domestic one) does not have the same effects on the individual bilateral trade flows. The trade with CZ, GB and IT manifests that an increase in the domestic GDP is linked to an increase in the value of the relevant international commodity transactions, but at the same time in trade with $D E$, FR and SK we do find the expected negative coefficient of estimation. Cointegrated partial trade balances with the GB support conclusions from the analysis at the overall bilateral level. In other cases, the results are mixed, and show the differences in the structure of trade flows and within individual product categories.

The parameter of foreign GDP again offers a little bit clearer conclusions. The theoretical assumptions of positive effects of foreign GDP on trade balance are not 
met in the case of GB. Other estimates support the theory of approximation of GDP to foreign demand for domestic goods and lead to an increased Polish exports. The overall bilateral effect of foreign GDP is supported by product categories with share in the bilateral foreign trade from $55 \%$ for DE up to $91 \%$ for FR. Cointegrated productlevel trade balances with SK fully correspond to the bilateral estimate.

Table 7 Estimated coefficients of long-term effects for Poland

\begin{tabular}{|c|c|c|c|c|c|c|c|c|c|c|c|c|c|c|c|c|c|c|}
\hline & & $\mathbf{C Z}$ & & & DE & & & FR & & & GB & & & IT & & & SK & \\
\hline & $Y d$ & $Y f$ & $E R$ & $Y d$ & $\boldsymbol{Y f}$ & $E R$ & $Y d$ & $Y f$ & $E R$ & $Y d$ & $Y f$ & $E R$ & $Y d$ & $\boldsymbol{Y f}$ & $E R$ & $Y d$ & $\boldsymbol{Y f}$ & $E R$ \\
\hline TT & 0.55 & 0.17 & 0.32 & -0.24 & 0.23 & 0.39 & -0.15 & 1.49 & 0.57 & 3.65 & -2.77 & 1.01 & 5.49 & 8.94 & 2.47 & -1.24 & 0.34 & 0.13 \\
\hline то & -0.23 & 0.87 & 0.73 & 0.40 & -4.96 & 0.53 & $\mathrm{x}$ & $\mathrm{x}$ & $\mathrm{x}$ & $\mathrm{x}$ & $\mathrm{x}$ & $\mathrm{x}$ & 0.60 & 2.43 & -1.21 & $\mathrm{x}$ & $\mathrm{x}$ & $\mathrm{x}$ \\
\hline T1 & -0.34 & 2.18 & -1.51 & 0.22 & 1.55 & 0.82 & 8.13 & -5.61 & 0.13 & $\mathrm{x}$ & $\mathrm{x}$ & $\mathrm{x}$ & 0.24 & 4.51 & 1.35 & -0.92 & 0.84 & -2.59 \\
\hline T2 & 3.08 & -4.26 & 0.21 & -2.10 & 3.64 & -0.71 & $x$ & $x$ & $\mathrm{x}$ & 0.29 & 4.39 & 1.03 & 6.23 & 1.51 & 0.77 & $\mathrm{x}$ & $x$ & $\mathrm{x}$ \\
\hline T3 & -0.41 & 0.38 & 0.57 & -1.73 & 0.65 & 028 & $\mathrm{x}$ & $\mathrm{x}$ & $\mathrm{x}$ & $\mathrm{x}$ & $\mathrm{x}$ & $\mathrm{x}$ & $\mathrm{x}$ & $\mathrm{x}$ & $\mathrm{x}$ & $\mathrm{x}$ & $\mathrm{x}$ & $\mathrm{x}$ \\
\hline T4 & $\mathrm{x}$ & $\mathrm{x}$ & $\mathrm{x}$ & $\mathrm{x}$ & $\mathrm{x}$ & $\mathrm{x}$ & $\mathrm{x}$ & $\mathrm{x}$ & $\mathrm{x}$ & $\mathrm{x}$ & $\mathrm{x}$ & $\mathrm{x}$ & $x$ & $\mathrm{x}$ & $\mathrm{x}$ & $\mathrm{x}$ & $\mathrm{x}$ & $\mathrm{x}$ \\
\hline T5 & & 1.80 & -1.52 & 0.34 & 2.03 & 0.44 & & 5.98 & 2.73 & $\mathrm{x}$ & $\mathrm{x}$ & $\mathrm{x}$ & 10.04 & -1.86 & -2.31 & 7.44 & 2.79 & 0.72 \\
\hline T6 & 1.25 & -0.77 & 0.62 & -0.61 & 1.16 & -0.01 & -0.95 & 4.02 & -0.85 & 2.83 & 0.34 & 2.12 & 1.33 & 1.73 & 0.34 & -1.40 & 3.94 & 3.68 \\
\hline T7 & -1.47 & 2.71 & -0.74 & 1.10 & -3.71 & 1.61 & 3.03 & 5.90 & -1.05 & 3.33 & -3.74 & 3.58 & 0.52 & 1.31 & 1.35 & -0.09 & 0.81 & 0.24 \\
\hline T8 & 0.14 & -0.67 & 2.23 & -1.91 & 2.05 & -0.98 & -4.02 & 10.13 & -1.75 & 5.78 & -1.20 & 0.84 & -0.70 & 3.64 & 1.79 & -3.18 & 3.07 & 2.71 \\
\hline T9 & $\mathrm{x}$ & $\mathrm{x}$ & $\mathrm{x}$ & $\mathrm{x}$ & $\mathrm{x}$ & $\mathrm{x}$ & $\mathrm{x}$ & $\mathrm{x}$ & $\mathrm{x}$ & $\mathrm{x}$ & $\mathrm{x}$ & $\mathrm{x}$ & $\mathrm{x}$ & $\mathrm{x}$ & $\mathrm{x}$ & $\mathrm{x}$ & $\mathrm{x}$ & $\mathrm{x}$ \\
\hline
\end{tabular}

Source: Author's calculations

The results of the paper show that the depreciation of the Polish zloty is associated with an improvement in bilateral trade balances with the countries analyzed. The highest coefficient of this effect was estimated for IT. Also the positive effect of PLN/GBP increase on the trade balance with GB is proved. Such a change leads to the substitution of products with cheaper Polish ones, to an increase in consumption caused by reduced prices expressed in GBP, possibly to a reduction of the volume of goods imported from GB as a consequence of increased prices expressed in PLN. Although the depreciation of the Polish zloty against the euro is associated with an increase in bilateral trade balances of all partners analyzed from the euro area, the estimates for territorial and commodity-territorial are not consistent again. Links between the PLN/EUR exchange rate and trade balance suggest improvement in the ratio of export to import in product categories representing 59\% of trade with $\mathrm{DE}$ and only $17 \%$ with FR. Although the depreciation of the Polish zloty against CZK demonstrates a positive effect on product-level trade balances representing $60 \%$ of the total foreign trade with $\mathrm{CZ}$, the results again confirm the problem of smoothing out of effects after aggregating data of different kinds of goods.

The analysis of long-term coefficients for the trade balance of Slovakia failed to assess the clear ties to its GDP. This conclusion is valid for both - bilateral and commodity level. Trade with AT, FR and HU represents a $14 \%$ average share of its 
total foreign trade, which is associated with an increase in trade balance after Slovakia's GDP growth. In contrast, trade flows, representing $40 \%$ of total trade, support the assumption of the primary impact of growth in domestic GDP on imports and hence the overall deterioration in the trade balance. Cointegration analysis at the product level corresponds largely with the bilateral analysis. The estimated coefficients in the case of PL differ between the analysis only in trade with beverages and tobacco, which represents less than one percent of their bilateral trade, in other analyzed models, this share ranges from 15 to $19 \%$.

Table 8 Estimated coefficients of long-term effects for Slovakia

\begin{tabular}{|c|c|c|c|c|c|c|c|c|c|c|c|c|c|c|c|c|c|c|}
\hline & & $\mathbf{A T}$ & & & CZ & & & DE & & & FR & & & HU & & & PL & \\
\hline & $Y d$ & $Y f$ & $E R$ & $Y d$ & $Y f$ & $E R$ & $Y d$ & $Y f$ & $E R$ & $Y d$ & $Y f$ & $E R$ & $Y d$ & $Y f$ & $E R$ & $Y d$ & $Y f$ & $E R$ \\
\hline TT & 1.13 & 2.27 & -1.14 & -2.76 & 3.08 & 0.12 & -0.56 & 4.12 & 0.55 & 0.07 & -0.17 & 0.34 & 0.52 & 1.27 & -0.14 & -1.07 & 2.18 & 0.12 \\
\hline TO & -0.40 & -0.46 & -0.32 & -1.15 & 1.27 & -0.90 & -0.70 & 2.32 & 0.22 & & -2.97 & -1.05 & & -5.63 & 0.29 & -0.87 & 3.56 & -0.45 \\
\hline T1 & -0.12 & 1.80 & 0.85 & -0.73 & 3.12 & 0.42 & 1.33 & 1.43 & -0.27 & 0.89 & 1.42 & 0.34 & 3.47 & -0.09 & -0.04 & 1.44 & 2.98 & 0.92 \\
\hline T2 & 0.07 & -0.05 & 0.11 & -2.96 & -0.09 & 1.01 & 1.09 & -0.98 & -0.18 & 1.14 & 0.94 & -0.22 & -1.09 & 1.24 & 1.08 & -3.76 & -2.59 & 0.51 \\
\hline T3 & $\mathrm{x}$ & $\mathrm{x}$ & $\mathrm{x}$ & 0.61 & 0.54 & 0.12 & -0.45 & 1.08 & 0.98 & -0.98 & 0.63 & 0.03 & -3.44 & 2.32 & 1.67 & -3.08 & -1.29 & -0.07 \\
\hline T4 & $\mathrm{x}$ & $x$ & $\mathrm{x}$ & $\mathrm{x}$ & $\mathrm{x}$ & $\mathrm{x}$ & $\mathrm{x}$ & $\mathrm{x}$ & $\mathrm{x}$ & $x$ & $\mathrm{x}$ & $\mathrm{x}$ & $X$ & $\mathrm{x}$ & $\mathrm{x}$ & $x$ & $x$ & $x$ \\
\hline T5 & -0.49 & 2.98 & -0.82 & -1.14 & -0.05 & 0.19 & 1.03 & 3.26 & -0.76 & -2.23 & -0.87 & 0.86 & -0.88 & -0.89 & 0.01 & -4.01 & 2.25 & -0.67 \\
\hline T6 & $\mathrm{x}$ & $\mathrm{x}$ & $\mathrm{x}$ & -0.07 & 1.39 & 0.88 & -0.70 & -0.09 & 1.03 & $\mathrm{x}$ & $\mathrm{x}$ & $\mathrm{x}$ & 1.08 & 3.01 & -0.54 & & -0.05 & 0.25 \\
\hline T7 & 3.05 & 1.15 & -0.32 & & 5.23 & 0.36 & -1.28 & 2.95 & 0.50 & 3.02 & 2.09 & 1.01 & 3.90 & 1.84 & 0.93 & & 1.34 & 0.18 \\
\hline T8 & -0.43 & 1.25 & 0.47 & 1.04 & 2.28 & -0.03 & -2.02 & 5.06 & 1.05 & -1.12 & 3.61 & 0.13 & 1.05 & 1.18 & 1.76 & 0.63 & 1.76 & 0.04 \\
\hline T9 & $\mathrm{x}$ & $\mathrm{x}$ & $\mathrm{x}$ & $\mathrm{x}$ & $\mathrm{x}$ & $\mathrm{x}$ & $\mathrm{x}$ & $\mathrm{x}$ & $\mathrm{x}$ & $\mathrm{x}$ & $\mathrm{x}$ & $\mathrm{x}$ & $X$ & $\mathrm{x}$ & $\mathrm{x}$ & $x$ & $\mathrm{x}$ & $\mathrm{x}$ \\
\hline
\end{tabular}

Source: Author's calculations

Clearer conclusions can be formulated in the case of foreign GDP for Slovakia as well. The theoretical assumption of direct relationship was not confirmed only for FR at the bilateral level. FR has the lowest share among Slovakia's analyzed trading partners. The inconsistency between bilateral and product-level analysis ranges from $9 \%$ to $29 \%$.

The results presented in Table 8 show a direct link between the exchange rate in direct quotation and bilateral trade balance with $\mathrm{CZ}, \mathrm{DE}, \mathrm{FR}$ and PL. Their average share in total foreign trade of Slovakia is $44 \%$ in the sample period. These results thus suggest that joining the euro area means a loss of one of the effective tools to adjust the trade balance. However, it is necessary to highlight the limitations of this analysis given by the shortened time series for AT, DE and FR resulting from the EUR adoption as the official currency of Slovakia and the revaluation of the central rate of SKK/EUR during Slovakia's participation in ERM II. 


\subsection{Discussion of the Results}

The lag analysis showed that delay of the effects of tested variables is on average higher for manufactured goods, machinery, transport equipment and miscellaneous manufactured articles. In these sectors we suppose the existence of longer delays caused by the existence of more long-term contracts and also time-consuming production. This means that these product categories respond after a longer period than other internationally traded goods. Although the number of cointegrated product-level trade balances is lower in some cases, the dominance in traded goods with a tendency to the long-term equilibrium can be observed. Based on this analysis it can be stated that the most of total bilateral and product-level trade balances are characterized by long-term joint motion with the development of domestic and foreign gross domestic product and a bilateral exchange rate, although the direction of their action is not always in line with the theoretical assumptions. The results of this work thus correspond to the findings of the studies by Šimáková (2012a, 2012b, 2014).

The analysis conducted further shows a long-term relationship between the exchange rate and foreign trade of V4 countries at the bilateral level in all tested trade balances with the exception of trade between Poland and Great Britain. As regards commodity distribution, a common feature of no long-term relationships between exchange rates and trade balances with animal and vegetable oils, fats, waxes and inconsistent product group of goods can be isolated, which due to their nature are not included in the other test categories and do not have any common characteristics. Inconsistency between bilateral and product-level results confirms the assumed bias resulting from the data aggregation. Diversity of effects of foreign exchange rates observed at the aggregate, bilateral and commodity levels is also confirmed in studies by Breuer and Clements (2003), Bahmani-Oskooee and Ardalani (2006), Baek (2006), BahmaniOskooee and Wang (2007) and Bahmani-Oskooee and Mitra (2008).

The findings of this paper show in some ways disunity with economic theory and cannot be clearly generalized across the countries or product categories analyzed. The ambiguous exchange rate effect on V4 foreign trade can be explained by several characteristics of interaction of these economies with the international commodity movements. V4 countries have import-intensive exports, significant presence of foreign direct investment. Many foreign companies with subsidiary branches in countries surveyed include multinational corporations operating in different territories. This fact implies their strong involvement in export and import transactions within multinational companies. Kiss and Schuszter (2014) also discuss the implications of corporate financing through loans in foreign currencies. All these attributes result in the fact that the bulk of international trade is related to the natural hedging. Čadek et al. (2011) performed an analysis of hedging in the case of Czech companies and found that the majority of exports are realized through the euro. Similar conclusions can also be found for the other V4 countries in the study by Égert-Zumaquera and Morales (2008). An important factor in the characteristics of foreign trade $\mathrm{V} 4$ is the degree of integration of trading partners. According to Martinez-Zarzoso and Ramos (2008), with the higher integration of economies, the volume of trade between them is increasing and exchange rates as one of the 
determinants act to a lower extent. V4 clearly show the importance of integrity for the implementation of foreign trade and for trade within the EU.

\section{Conclusions}

The paper deals with the relationship between exchange rates and foreign trade. The aim of this paper was to reveal the long-term effects of the level of exchange rates on the trade balances of the Visegrad Countries. Analysis is based on the assumption that different product categories are characterized by different price elasticity of traded goods and exchange rate development faces risk aversion to various degrees in every country. There are entities with a variety of consumer and producer behavior patterns. Hence, the paper contributes to the economic studies dealing with the postcommunist countries which are fully transformed into a market economy by the use of relatively new territorial-commodity approach. Because the paper represents a study focusing on V4 and employs disaggregated product-level data of bilateral trade with the largest trading partners, the greatest contribution of this study is its more detailed results. The territorial and commodity approach applied also helps to reduce distortion caused by the aggregation bias.

The analysis performed shows a long-term relationship between the exchange rate and foreign trade of V4 countries at a bilateral level in all cases, except the trade between Poland and Great Britain. This fact is probably caused by the diversity of structures of their economies. Results for other trade flows thus support the claims of long-term trend towards the mutual development of the V4 bilateral trade balances and their level of exchange rates. Product-level analysis pursues a common feature of no long-term relationships in the case of trade balance with animal and vegetable oils, fats, waxes and inconsistent product groups of commodities and transactions not classified elsewhere in the SITC, which due to their nature cannot be included in other tested categories. Hence, this kind of group does not show the common characteristic features of behavior. The lag structure differs more across different product categories than across different trading partners. In general, higher lags are typical for groups of manufactured goods, machinery and transport equipment and miscellaneous manufactured articles. These categories of goods are supposed to be purchased under long-term contracts, and it usually takes more time to adapt to new price conditions. Although there are some product categories without proved cointegration, the product categories tending to the long-term equilibrium significantly exceed them. Based on this analysis it can be stated that the bulk of the total and partial bilateral trade balances are characterized by a common long-term development with domestic and foreign GDP and bilateral exchange rates.

In summary, the results based on disaggregated data clearly demonstrate that the role and effect of exchange rates on V4 foreign trade are not definite. Although there are clearly demonstrated links between exchange rate and foreign trade, one cannot simply assume that the depreciation of domestic currency will boost exports, reduce imports and, hence, improve the trade balance. This conclusion can be associated with the fact that V4 exporters and importers intensively hedge their foreign trade activities, V4 exports are significantly dependent on imports, and V4 companies are largely owned by foreign investors and belong to multinational corporations. 
Therefore, product groups and trading partners should be carefully distinguished when considering exchange rate effects on foreign trade.

The use of product-level data also allows the identification of sectors that are more affected by the exchange rates. This approach enables to isolate the specific effects of exchange rate development on specific trade flows. This practical benefit of the paper for the corporate sector is based on a demonstration of the need to differentiate the regional characteristics of the markets where they could place their production as well as the types of products that will be held for trading in selected foreign markets. The results obtained can be further taken into account by national central banks of each country in assessing the potential impact of the current exchange rate policy. Conclusions can also be used in the development of targeted policies to promote foreign trade of specific products through foreign exchange interventions on the domestic currency. The findings demonstrate that steps of their central banks towards the stability of the exchange rate could reflect in increasing of the total turnover of internationally traded goods.

\section{Acknowledgments}

Publication of this paper was supported by the Ministry of Education, Youth and Sports within the Institutional Support for Long-term Development of a Research Organization in 2016. The support is gratefully acknowledged.

\section{References}

Arize, A. C. (1994). Cointegration Test of a Long-Run Relation between the Real Effective Exchange Rate and the Trade Balance. International Economic Journal, 8(3), pp. 1-9.

Auboin, M. and Ruta, M. (2013). The Relationship between Exchange Rates and International Trade: a Literature Review. World Trade Review, 12(3), pp. 577-605.

Baek, J. (2006). The J-curve effect and the US-Canada forest products trade. Journal of Forest Economics, 13, pp. 245-258.

Bahmani-Oskooee, M. and Ardalani Z. (2006). Exchange Rate Sensitivity of U.S. Trade Flows: Evidence from Industry Data. Southern Economic Journal, 72(3), pp. 542-559.

Bahmani-Oskooee, M. and Brooks, T. (1999). Cointegration Approach to Estimating Bilateral Trade Elasticities between U.S. and Her Trading Partners. International Economic Journal, 13(1), pp. 119-128.

Bahmani-Oskooee, M., Aftab, M. and Harvey, H. (2016). Asymmetry Cointegration and the J-curve: New Evidence from Malaysia-Singapore Commodity Trade. The Journal of Economic Asymmetries, 14 (part B), pp. 211-226. DOI: 10.1016/j.jeca.2016.10.001.

Bahmani-Oskooee, M., Harvey, H. and Hegerty, S. (2014). Brazil-US Commodity Trade and the J-Curve. Applied Economics, 46(1), pp.1-13.

Bahmani-Oskooee, M. and Hegerty, S. (2011). The J-curve and NAFTA: Evidence from Commodity Trade between the U.S. and Mexico. Applied Economics, 43(13), pp. 1579-1593.

Bahmani-Oskooee, M. and Mitra, R. (2008). Exchange Rate Risk and Commodity Trade between the US and India. Open Economies Review, 19(1), pp. 71-80. 
Bahmani-Oskooee, M. and Ratha, A. (2004). The J-Curve: A Literature Review. Applied Economics, 36(13), pp. 1377-1398.

Bahmani-Oskooee, M. and Wang, Y. (2007). United States-China Trade at the Commodity Level and the Yuan-Dollar Exchange Rate. Contemporary Economic Policy, 25(3), pp. 341-361.

Breuer, J. B. and Clements, L. A. (2003). The Commodity Composition of USJapanese Trade and the Yen/Dollar Real Exchange Rate. Japan and the World Economy, 15(3), pp. 307-330.

Čadek et al. (2011). Hedge Behaviour of Czech Exporting Firms. Czech National Bank Working Paper Series 14/2011.

Égert-Zumaquera, B. and Morales, A. (2008). Exchange Rate Regimes, Foreign Exchange Volatility, and Export Performance in Central and Eastern Europe: Just another Blur Project? Review of Development Economics, 12, pp. 577-593.

Felmingham, B. (1988). Where Is The Australian J-Curve? Bulletin of Economic Research, 40(11), pp. 43-56.

Fojtíková, L. (2011). Opatření zahraničně obchodní politiky a otevřenost ekonomiky v zemích Visegrádské skupiny. Ekonomická revue, 14, pp. 51-66.

Kiss, G. D. and Schuszter, T. (2014). What are the Differences between the Currencies of Foreign Exchange Loans? Public Finance Quarterly, 59(2), pp. 187-206.

Martinez-Zarzoso, I. and Ramos, L. (2008). The Effect of Trade Facilitation on Sectoral Trade. The B.E. Journal of Economic Analysis \& Policy, 8(1), pp. 1-46.

Mirdala, R. (2011). Menové kurzy v krajinách strednej Európy. Košice: Technická unvierzita v Košiciach.

Rose, A. K. and Yellen. J. L. (1989). Is there a J-curve? Journal of Monetary Economics, 24(1), pp. 53-68.

Šimáková, J. (2012a). Bilateral J-Curve between Slovakia and its Major Trading Partners. In: Proceedings of the 30th International Conference Mathematical Methods in Economics 2012. Karviná: OPF SU Karviná, pp. 864-869.

Šimáková, J. (2012b). Estimation of the J-Curve Effect: The Case of the Visegrad Group. In: EBES 2012 Warsaw Conference Program and Abstract Book. Istanbul: Teknik Basim Matbaacilik, pp. 38-39.

Šimáková, J. (2014). The Effects of Exchange Rate Change on the Trade Balance of Slovakia. The European Financial and Accounting Journal, 9(3), pp. 50-66. 